\title{
ECONOMIC ASPECTS OF FINANCING THE TOURISM INVESTMENTS FROM THE EUROPEAN REGIONAL DEVELOPMENT FUND IN LUBLIN CITY DISTRICT
}

\author{
ANNA KATARZYNA MAZUREK-KUSIAK, ${ }^{1}$ BOGUSŁAW SAWICKI ${ }^{2}$
}

University of Life Sciences, Department Tourism and Recreation, Lublin, POLAND

${ }^{1}$ e-mail:anna.mazurek@up.lublin.pl

${ }^{2}$ e-mail: boguslaw.sawicki@up.lublin.pl

\section{RECEIVED}

ACCEPTED

JEL

CLASSIFICATION

KEYWORDS

ABSTRACT
18 January 2018

2 September 2018

$\mathrm{H} 79, \mathrm{R} 51, \mathrm{Z} 32$

fund, city district, finance, tourism investments, European Regional Development Fund

The aim of the study is to determine the quantitative and qualitative effects of co-financing tourism investments of the European Regional Development Fund in the years 2004-2013 in the city of Lublin. Study was conducted with reference to the financial perspective of the European Union for 2004-2006 and 2007-2013 and related to the financial support of the EU tourism sector in the city of Lublin. Present study used original and secondary results. Primary research was conducted using the diagnostic survey method, using a direct interview conducted among 137 employees of the tourism industry employed in Lublin, which was designed to assess the effectiveness of spending the aid. Secondary studies consisted of analyzing reports on the implementation of projects and spending European Funds. Overall, the EFRR co-financing of tourist investments realized in the Lublin city district in 2004-2013 amounted to PLN 117,762,774.3, which accounted for $35.32 \%$ of the total value of the projects. It follows that without this help a lot of investment would be unrealized. It was found that only $41.61 \%$ of the surveyed population assessed positive investments and $25.55 \%$ of respondents were negative, while $16.06 \%$ had not any opinion at all. This demonstrates the weak orientation of professional workers in professional matters. The cause of such a state of consciousness may lie in the poor promotion of investment with the support of EU funds. Investments made in Lublin due to the European Union subsidies should contribute not only to the growth of potential of the local tourist economy, but also to the overall economic development.

\section{Introduction}

For many years, tourism has been the most rapidly developing national economy among national economies. It has a large impact on GDP growth and the number of direct and indirect market players (Horodecka, 2008, p. 18). It is worth emphasizing, however, that in many countries it is not well appreciated and taken into account in national and regional policy (Wanhill, 2002, pp. 8-11). Different and more objective reasons for this are decisive, as the 
tourist market is characterized by an extensive network of trade missions (European Commission). Generally, this market includes tourist demand and supply, and price and terms of sale (Panasiuk, 2014, p. 104; Panasiuk, 2012, pp. 357-370).

At present, economic innovations are particularly appreciated by the innovativeness of the national economy (Stauvermann, Kumar, 2017, pp. 426-433), including the tourism economy, hence the governmental and local sphere of Poland undertake many actions aimed at increasing the innovativeness of the tourist economy. Probably from here Poland initiated the step by step preparation of the National Strategy for Regional Development, which takes into account the development of tourism (Pysiak, 2006, p. 198; Nuszkiewcz, Roman, 2013, pp. 6-7).

In order to promote the development and innovativeness of the economy, including the tourism economy, the European Union has set up structural funds, which are supposed to influence the actions of local governments and market actors related to the tourism economy in a diversified way (Pysiak, 2006, pp. 198-209; Banerjee, Cicowiez, Cotta, 2016, pp. 115-138). They include:

1. European Regional Development Fund (EFRR).

2. European Social Fund (EFS).

3. European Agricultural Guidance and Guarantee Fund (EFOiGR).

4. Cohesion Fund (FS).

Panasiuk (2016, pp. 93-94) writes that the aforementioned funds from the European Union have a significant impact on the activities of local government units, including the development of tourist offer through the development of tourist and para-tourist infrastructure, promotion of the product and shaping the image of the tourist area, yet there is quite large regional differentiation here.

The aim of the study is to determine the quantitative and qualitative effects of co-financing tourism investments of the European Regional Development Fund in the years 2004-2013 in the county of Lublin.

\section{Material and Methods}

The study was conducted with reference to the financial perspective of the European Union for 2004-2006 and 2007-2013 and related to the financial support of the EU tourism sector in the county of Lublin. Present study used original and secondary results. Primary research was conducted using the diagnostic survey method, using a technique of direct interview that was conducted among 137 employees of the Lublin tourism sector. They assessed the effectiveness of spending the aid. Secondary studies consisted of analyzing reports on spending the European funds for realized projects. Data originated from available reports. In addition, observation and quantitative methods along with methods of logical operations, as well as monograph method, were used. The Excel 2016 spreadsheet was used for the calculations.

\section{Characteristics of the research area}

Lublin is the largest city in the eastern part of Poland and the capital of Lublin province. Its area is $147.5 \mathrm{~km}^{2}$ and 340.5 thousand residents live here. The city is situated on Lublin Upland, Nałęczów Plateau, Bełżyce Plain and Wyniosłość Giełczewska (Turski, Wyszkowski, 2006, p. 74). The city now has partnership agreements with 25 cities around the world. These include Münster and Delmenhorst in Germany, Lublin in Wisconsin, USA, Tbilisi in Georgia, Debrecen in Hungary, Lwów, Lutsk and Starobielsk in Ukraine, Windsor in Canada and Viseu in Portugal (Kawałko, 2012, pp. 575-576). 
The rich cultural resources of Lublin make the city more and more interesting for tourists and it is an excellent base for local, national, and foreign trips. In addition, such destinations as Janowiec, Kazimierz Dolny, Kozłówka, Naleczow, Zamość are some of the most unique objects, not only in the Lublin region, but also in the whole Poland. They are well known to tourists due to their location, history and unique natural values (Kowalczyk, 2011, p. 73). For many years, Lublin has hosted many cultural events as well as film, music and theater festivals that attract many tourists. At the beginning of June, there is Night of Culture, which transforms the streets of Lublin into one big stage of unique cultural events and atypical installations. During the holidays, there is Jagiellonian Fair, Magicians Carnival, Festival of Other Sounds, International Folklore Meetings. September is the month, when Lublin becomes the capital of cooks, as the European Festival of Taste takes place. During the autumn and winter, there are International Dance Theater Meetings, International Jazz Festival and International Performance Festival. Thanks to all these events, Lublin participated in the final of the competition for the title of European Capital of Culture in 2016 (Nowak, 2014, pp. 15-32).

\section{Results and Discussion}

The analysis of the Lublin Development Strategy shows that the main goals of tourism development in Lublin include:

- increase of economic importance in economic development,

- increase in the quality of life of residents and improvement of the quality of the environment,

- cooperation and integration for tourism and its environment in the social, spatial and economic dimension.

In general, these are correctly identified goals, which is also noticed by other authors (Balcerzak-Kaleta, Raźniewski, 2009a, pp. 244-254), but the essence is their detailed understanding and dynamic implementation.

Until 2004, Poland used the pre-accession assistance, i.e. funds intended for countries applying for membership in the European Union. After joined the EU in May 2004, Poland could continue to use the preaccession aid and, in addition, as a full member of the EU, to receive new support. Between 2004 and 2006, EU funds were used for the first time on the same basis as other Member States (Balcerzak-Kaleta, Raźniewski, 2009b, pp. 244-254). The years 2007-2013 are another programming period, under which Poland was granted the support for development of individual regions and the whole country, so that the standard of living of the population approached the European standards, which is shown in Table 1.

Table 1. Value of funds from the European Regional Development Fund to finance investment in tourism in the Lublin city district in 2004-2006 and 2007-2013

\begin{tabular}{lcccc}
\hline \multicolumn{1}{r}{ Years } & Number of projects & Value of project in w PLN & Financing from EU in PLN & \% of financing \\
\hline $2004-2006$ & 4 & $27,859,866.69$ & $19,581,455.90$ & 70.29 \\
$2007-2013$ & 51 & $305,531,507.59$ & $98,181,318.38$ & 32.13 \\
\hline Total & 55 & $333,391,374.30$ & $117,762,774.30$ & 35.32 \\
\hline
\end{tabular}

Source: own study own study based on www.mapadotacji.gov.pl (15.07.2017).

The value of investment in tourism in 2004-2006 amounted to almost 28 million, including over 19.6 million received as the EU subsidy from the Integrated Regional Operational Program. It is also worth noting that Lublin 
received EU funds at the $70 \%$ co-financing level (Table 1). The funds for extension were granted by the Provincial Public Library. H. Łopaciński in Lublin (PLN 7.5 million); The Arch. St. John the Baptist and St. John the Evangelist in Lublin for the 3rd stage of renovation and organization of the Museum of the 200th anniversary of the Archdiocese of Lublin (PLN 6 million); The Lubelskie Museum for the protection and maintenance of the Lublin Castle (PLN 5.5 million) and the Provincial Headquarters of the State Fire Service in Lublin to provide a sense of security for tourists through the creation of a public safety zone in the area of Metalurgiczna Street in Lublin (PLN 0.5 million).

In 2007-2013, The City District received subsidies from the European Union of 98 million for the implementation of 51 tourism projects. This grant covered $32.13 \%$ of all investment in tourism (Table 1). The largest co-financed investments are the construction of an exhibition and congress and conference facility dedicated to the presentation and promotion of innovative solutions in entrepreneurship and science (PLN 36 million) and the construction of the Regional Exhibition and Show Center in Lublin (PLN 16 million). These projects have contributed to increasing the tourist attractiveness of the city. Due to the European Funds, the city of Lublin nowadays is a real pearl among the monuments of architecture and urbanism of the whole region. Development of accommodation and recreational facilities occurred, congressional and trade tourism has been developed dynamically, as well as events related to thematic areas with Lublin industrial specialization, aimed at intensifying international contacts, especially in the area of Eastern Partnership. This also results in increased employment in the tourism sector.

Lublin received the most financial resources for investments in the tourism industry from the Operational Program Development of Eastern Poland, as much as nearly PLN 52 million, which constitutes $43.88 \%$ of all received subsidies in 2004-2013. From this program, only two investments were realized (Lublin Conference Center and II stage of construction of the Regional Exhibition and Fair Center in Lublin). Both investment projects reached over PLN 136 million, of which 38\% were from the European Union. Up to 48 projects have been financed from the Regional Operational Program of Lubelskie Province amounting to over PLN 46 million, which accounts for $39.24 \%$ of grants received during the period considered. Lublin received the least funds from the Regional Operational Program of the Podlaskie Province, which were dedicated to the creation of a spa and wellness center in the Czarnecki Manor. This investment included three counties: Białystok, Lublin and Lublin city (Table 2).

Table 2. Programs involved in financing investment in tourism in the Lublin city district in 2004-2006 and 2007-2013

\begin{tabular}{lccccccc}
\hline \multicolumn{1}{c}{ Program } & \multicolumn{2}{c}{ Projects } & \multicolumn{2}{c}{ Value of project } & \multicolumn{2}{c}{ Financing from EU in PLN } & \% of financing \\
\cline { 2 - 7 } & number & $\%$ & in PLN & $\%$ & in PLN & $\%$ & 37.96 \\
\hline $\begin{array}{l}\text { Operational Program Development } \\
\quad \text { of Eastern Poland 2007-2013 }\end{array}$ & 2 & 3.64 & $136,104,262.73$ & 40.82 & $51,669,976.18$ & 43.88 \\
$\begin{array}{l}\text { Integrated Operational Program of Regional } \\
\quad \text { Development 2004-2006 }\end{array}$ & 4 & 7.27 & $27,859,866.69$ & 8.36 & $19,581,455.90$ & 16.63 & 70.29 \\
$\begin{array}{l}\text { Regional Operational Program of the } \\
\quad \text { Podlaskie Province 2007-2013 }\end{array}$ & 1 & 1.82 & $877,770.38$ & 0.26 & $304,032.87$ & 0.26 & 34.64 \\
$\begin{array}{l}\text { Regional Operational Program of the Lublin } \\
\text { Province 2007-2013 }\end{array}$ & 48 & 87.27 & $168,549,474.48$ & 50.56 & $46,207,309.33$ & 39.24 & 27.41 \\
\hline Total & 55 & 100.00 & $333,391,374.00$ & 100.00 & $117,762,774.00$ & 100.00 & 35.32 \\
\hline
\end{tabular}

Source: own study own study based on www.mapadotacji.gov.pl (15.07.2017).

Only in the Lublin city district, there were 43 projects financed by the European Regional Development Funds with a total value of over PLN 305 million, including $35.51 \%$ of the subsidy. On the other hand, more than one 
administrative unit implemented 12 projects worth nearly PLN 28 million and PLN 9 million of subsidies (Table 3). The projects were implemented jointly with the districts of Radzyń, Lublin, Wlodawa, Zamość, Łuków, Białystok, Lubartów, Tarnów, Cieszyn, Bieruń-Lędziny and Gliwice.

Table 3. Area of implementation of projects from the European Regional Development Funds in the district of Lublin city in 2004-2013

\begin{tabular}{lccrrrrr}
\hline \multirow{2}{*}{ Project realization } & \multicolumn{2}{c}{ Projects } & \multicolumn{2}{c}{ Value of project } & \multicolumn{2}{c}{ Financing from EU in PLN } & \multirow{2}{*}{ \% of financing } \\
\cline { 2 - 7 } & number & per cent & \multicolumn{1}{c}{ in PLN } & per cent & in PLN & per cent & \\
\hline Only in Lublin city district & 2 & 3.64 & $136,104,262.73$ & 40.82 & $51,669,976.18$ & 43.88 & 37.96 \\
On a larger area than Lublin city district & 4 & 7.27 & $27,859,866.69$ & 8.36 & $19,581,455.90$ & 16.63 & 70.29 \\
\hline Total & 1 & 1.82 & $877,770.38$ & 0.26 & $304,032.87$ & 0.26 & 34.64 \\
\hline
\end{tabular}

Source: own study own study based on www.mapadotacji.gov.pl (15.07.2017).

By analyzing data presented in Table 4, it can be seen that the most co-financed investments were related to the organization of cultural and tourist events (over PLN 140 million, including 37.73\%). The second place included investments related to the accommodation and catering facilities (over PLN 126 million, including co-financing amounting to $28.05 \%$ ). In the third place, the development, construction and modernization of sports and recreation facilities was appreciated, as over PLN 36 million was spent, receiving EU funding in the amount of PLN 8 million, which accounted for $22.17 \%$ of all expenditures. The fourth position was taken by the development of culture, where over PLN 28 million was spent, but the value of co-financing from EU funds reached the level of $70.05 \%$.

Table 4. Directions of investment implementation in the field of tourism in Lublin city district in 2004-2013

\begin{tabular}{|c|c|c|c|c|c|c|c|}
\hline \multirow{2}{*}{ Investment in } & \multicolumn{2}{|c|}{ Projects } & \multicolumn{2}{|c|}{ Value of project } & \multicolumn{2}{|c|}{ Financing from EU in PLN } & \multirow{2}{*}{$\begin{array}{c}\% \\
\text { of financing }\end{array}$} \\
\hline & number & $\%$ & in PLN & $\%$ & in PLN & $\%$ & \\
\hline Base for organizing cultural and tourist events & 5 & 9.09 & $140,132,481.75$ & 42.03 & $52,878,330.52$ & 44.90 & 37.73 \\
\hline Accommodation and catering & 33 & 60.00 & $126,502,768.24$ & 37.94 & $35,486,158.41$ & 30.13 & 28.05 \\
\hline Cultural development & 5 & 9.09 & $28,774,184.65$ & 8.63 & $20,156,355.33$ & 17.12 & 70.05 \\
\hline Development of sports and recreation facilities & 10 & 18.18 & $36,178,259.08$ & 10.85 & $8,021,044.19$ & 6.81 & 22.17 \\
\hline Others & 2 & 3.64 & $1,803,680.56$ & 0.54 & $1,220,885.83$ & 1.04 & 67.69 \\
\hline Total & 55 & 100.00 & $333,391,374.28$ & 100.00 & $117,762,774.00$ & 100.00 & 35.32 \\
\hline
\end{tabular}

Source: own study own study based on www.mapadotacji.gov.pl (15.07.2017).

It is interesting to look at the assessment of equity of EU funds disbursed by travel industry workers. Most respondents (41.41\%) positively assessed the investment subsidy. Among the motifs of the assessment, there were: increase of the attractiveness of the city, development of culture and growth of tourism in the city, which led to increased employment in the tourist industry. In opinion of $25.55 \%$ respondents, the aid was not effectively spent and well suited to the needs of tourists, as the short deadline for application preparation, bureaucracy and formalization of applications, the need for self-contribution has made it impossible for any entity to be able to obtain such support, which reduced the availability of funds for a wide range of social groups (Figure 1). 


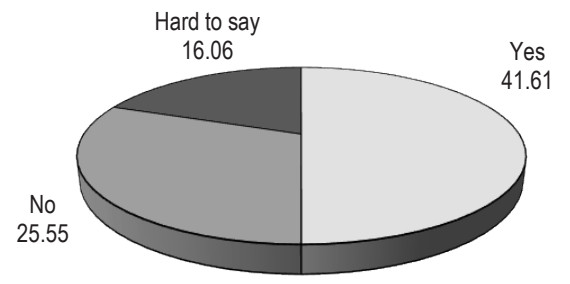

Figure 1. Evaluation of the effectiveness of spending aid from the European Regional Development Fund in respondents' opinions

Source: own study based on diagnostic survey.

Another issue assessed by the respondents was the assessment of subsidized investments from a professional and social point of view (Figure 2). In this case, they most appreciated the investment referred to as Protection and Renovation of the Lublin Castle (32.85\% of indications). This project received PLN 5.5 million from the European Regional Development Fund. Its essence was the general renovation of the monument, which was long delayed due to no possibility of financing. During the 21 months of the project implementation (from 1 October 2006 to 30 June 2008), all planned maintenance and repair works were carried out. An important element of the project was to increase accessibility for people with disabilities. In addition, the archaeological research carried out during the renovation has contributed to the enrichment of knowledge about the oldest history of the castle hill. Traces of settlement and the existence of man thousands years ago BC, were discovered here. Second place was the construction of the Regional Exhibition and Fair Center in Lublin (23.36\% of indications).

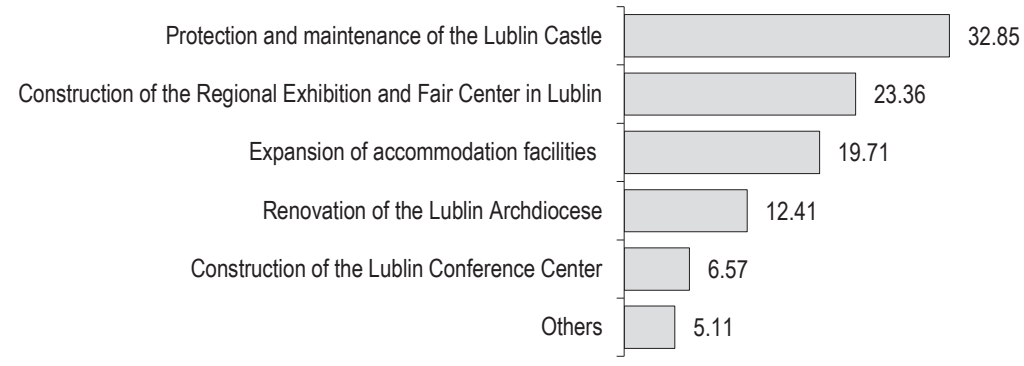

Figure 2. The best investments made from the European Regional Development Fund in respondents' opinions

Source: own study based on diagnostic survey.

The project was based on the construction of an exhibition hall of 8 thousand square meters, modernization of the exhibition area in the existing hall (2.5 thousand square meters), construction of 2 conference rooms for 150 people each and adaptation of the existing facility to the possibility of organizing conferences for 1,500 people, creation of an external exhibition area of 5 thousand square meters and creation of about 500 new parking spaces. These elements contributed to the possibility of organizing cultural and sports events for 5,000 people (at one time). Specialty of the Fair are events related with the areas of Lublin industrial specialization, aimed at 
intensifying international contacts, especially in the area of Eastern Partnership. Third place was the expansion of accommodation (19.71\% of indications). Due to the EU funds, new hotels such as Hotel Wieniawski, Focus II, Willowa, "Nad Zalewem" and Agit, accommodation for less demanding clients "Grodzka 20", "Trybunalska", as well as hotels and lodgings, were opened in the vicinity of Lublin. According to $12 \%$ of respondents, the best investment funded by EU funds was the renovation of the Arch. St. John the Baptist and St. John and the organization of the Museum of the 200th anniversary of the Archdiocese of Lublin. During the project, renovation of wall polychrome and portals of the Treasury and the Acoustical Chapel was carried out. In addition to conservation work, an important part of the project was the exposition of priceless monuments of sacred art - liturgical vestments and goldsmithery objects. The renovated rooms are equipped with 23 illuminated display cabinets with exhibits. The lighting of the late Baroque polychrome by Joseph Meyer from 1755-1758 was also installed. The third stage of the work also covered the conservation of the polychrome vault and walls of 5 chapels: Angels, St. Gonzaga, St. Nepomucen, St. Xavier, St. Mary Magdalene and 6 the altars. An important part of the project was the conservation of antique liturgical vestments. The construction of the Lublin Conference Center was appreciated by only $6.57 \%$ of the surveyed people, which proves the low knowledge of employees of the tourism industry in the field of business tourism. The exhibition hall of $2,500 \mathrm{~m}^{2}$ serves to present and promote the achievements of innovative companies. There are demonstrations and exhibitions on innovative products from various industries, especially the high-tech. In addition, it is a place of presentation of the offer of business institutions supporting innovation. The knowledge festivals are periodically held in the hall, where multimedia presentations of study programs, and television broadcasts from research laboratories with spectators take place.

\section{Conclusions}

1. Overall, the EFRR co-financing of tourist investments realized in the Lublin city district in 2004-2013 amounted to PLN $117,762,774.3$, which accounted for $35.32 \%$ of the total value of the projects. It follows that without this help a lot of investment in the field of tourist and para-tourism infrastructure, would not be realized.

2. While examining the opinion among employees of the tourist industry on the appropriateness of funds spent, it was found that only $41.61 \%$ of the sample assessed the investments positively and $25.55 \%$ of respondents were negative, $16.06 \%$ did not have any opinion on this. This indicates poor orientation of professional employees in professional matters. The reason for this state of consciousness may also lie in the poor promotion of investment accomplishments with the support of EU funds. In this situation, promotional and educational activities are necessary.

3. Respondents rated the protection and conservation of Lublin Castle the best ( $32.85 \%$ of responses), and in the second place, the Construction of Regional Fair and Exhibition Center (23.36\%). However, it is disturbing that only $6.57 \%$ of surveyed employees in the tourist industry appreciated the construction of Lublin Conference Center. This proves their incomplete knowledge of business tourism, which seems to be highly disturbing and requiring catching up with this state of knowledge.

4. Investments made in Lublin due to the European Union subsidies should contribute not only to the growth of potential of the local tourist economy, but also to the overall economic development, however, it is necessary here the parallel development of education of the tourism industry employees to be able to appreciate and use the created tourist and para-tourism infrastructure. 


\section{References}

Balcerzak-Kaleta, J., Raźniewski, P. (2009a). Kultura i turystyka. In: J. Balcerzak-Kaleta (ed.), Analiza aktualnej sytuacji, trendów rozwojowych i prognoza zmian społeczno-gospodarczych w województwie lubelskim (pp. 186-209). Lublin: Instytut Badań i Analiz Olsztyńskiej Szkoły Biznesu.

Balcerzak-Kaleta, J., Raźniewski, P. (2009b). Wsparcie finansowe Unii Europejskiej. In: J. Balcerzak-Kaleta (ed.), Analiza aktualnej sytuacji, trendów rozwojowych i prognoza zmian społeczno-gospodarczych w województwie lubelskim (pp. 244-254). Lublin: Instytut Badań i Analiz Olsztyńskiej Szkoły Biznesu.

Banerjee, O., Cicowiez, M., Cotta, J. (2016). Economics of tourism investment in data scarce countries. Annals of Tourism Research, $60,115-138$.

Horodecka, A. (2008). Ewolucja celów polityki gospodarczej. Rola zmian otoczenia. Warszawa: Wydawnictwo Naukowe PWN.

Kawałko, P. (2012). Lublin. Przewodnik. Lublin: Wydawnictwo Gaudium.

Kowalczyk, I. (2011). Zwiedzamy Lublin Przewodnik. Lublin: „Kami” Biuro Usług Pilotarskich i Przewodnickich.

Nowak, B. (2014). Lublin - przewodnik. Lublin: Wydawnictwo Test.

Nuszkiewicz, K., Roman, M. (2013). Innowacje w rozwoju turystyki. Golądkowo: Wydawnictwo SGGW.

Panasiuk, A. (2012). Popyt turystyczny jako obszar polityki społeczno-gospodarczej w Polsce. Zeszyty Naukowe Uniwersytetu Szczecińskiego, 697. Ekonomiczne Problemy Usług, 82, 357-370.

Panasiuk, A. (2014). Relacje na rynku turystycznym. Zeszyty Naukowe Uniwersytetu Szczecińskiego, 805. Ekonomiczne Problemy Turystyki, 1 (25), 101-114.

Panasiuk, A. (2016). Ocena wpływu funduszy UE w gospodarce turystycznej a wielkość ruchu turystycznego. Ekonomiczne Problemy Turystyki, 1 (33), 93-106.

Pysiak, B. (2006). Innowacje w regionie. In: M. Strużyński (ed.), Innowacyjność w teorii i praktyce (pp. 198-209). Warszawa: Wydawnictwo SGGW.

Stauvermann, P.J., Kumar, R.R. (2017). Productivity growth and income in the tourism sector: Role of tourism demand and human capital investment. Tourism Management, 61, 426-433.

Turski, S., Wyszkowski, M. (2006). Lubelszczyzna przewodnik. Lublin: Wydawnictwo BESPOL.

Wanhill, S. (2002). Sustaining tourism SMEs. VII Congreso Internacional del CLAD sobre la Reforma del Estadoydela Administración Pública. Portugal: Lisboa, 8-11. Retrieved from: http://unpan1.un.org/intradoc/groups/public/documents/CLAD/clad0044547.pdf. www.mapadotacji.gov.pl.

Cite this article aS: Mazurek-Kusiak, A., Sawicki, B. (2018). Economic aspects of financing the tourism investments from the European Regional Development Fund in Lublin city district. European Journal of Service Management, 3 (27/2), 281-288. DOI: 10.18276/ ejsm.2018.27/2-34. 